\title{
A new species of the genus Protapatophysis Semenov-Tian-Shanskij et Stshegoleva-Barovskaja, 1936 (Coleoptera: Cerambycidae) from Pakistan
}

\section{Новый вид жкуков-дровосеков рода Protapatophysis Semenov-Tian- Shanskij et Stshegoleva-Barovskaja, 1936 (Coleoptera: Cerambycidae) из Пакистана}

\author{
Alexandr I. Miroshnikov ${ }^{1,2}$ \\ А.И. Мирошников ${ }^{1,2}$
}

${ }^{1}$ Russian Entomological Society, Krasnodar, Russia. E-mail: miroshnikov-ai@yandex.ru
${ }^{2}$ Sochi National Park, Moskovskaya str., 21, Sochi, Krasnodar region 354002, Russia.
${ }^{1}$ Русское энтомологическое общество, Краснодар, Россия.
${ }^{2}$ Сочинский национальный парк, ул. Московская, 21, Сочи, Краснодарский край 354002, Россия.

KEY WORDS: Coleoptera, Cerambycidae, Protapatophysis, new species, Pakistan, Hindukush.

КЛЮЧЕВЫЕ СЛОВА: Coleoptera, Cerambycidae, Protapatophysis, новый вид, Пакистан, Гиндукуш.

ABSTRACT. A new species, Protapatophysis hindukushensis Miroshnikov, sp.n., is described from Pakistan. It differs from all congeners by the somewhat peculiar shape of the lateral tubercles of the pronotum, the structure of the genitalia, as well as by the poorly developed discal tubercles of the pronotum and the shorter antennae, especially in comparison with P. kashmiriana (Semenov, 1901), P. vartianae (Heyrovský, 1971) and P. kabakovi Danilevsky, 2011.

РЕЗЮМЕ. Описан новый вид Protapatophysis hindukushensis Miroshnikov, sp.n. из Пакистана. Он отличается от всех видов рода несколько своеобразной формой боковых бугров переднеспинки, строением гениталий, а также слабо развитыми буграми на диске переднеспинки и более короткими усиками, особенно по сравнению с P. kashmiriana (Semenov, 1901), P. vartianae (Heyrovský, 1971) и $P$. kabakovi Danilevsky, 2011.

\section{Introduction}

Until now, four species of the genus Protapatophysis Semenov-Tian-Shanskij et Stshegoleva-Barovskaja, 1936 have been known [Danilevsky, 2011; Miroshnikov, 2014], namely P. kashmiriana (Semenov, 1901), P. montana (Gahan, 1906), P. vartianae (Heyrovský, 1971) and P. kabakovi Danilevsky, 2011. However, with respect to one male originating from the northernmost parts of Pakistan (Hindukush, Chitral Valley), it was pointed out [Miroshnikov, 2014: 19] that this specimen most likely belongs to a yet undescribed species.

This paper describes a new species based just that male.

The material treated here belongs to the following institutional and private collections:

BMNH — Natural History Museum (London, United Kingdom);

ZIN - Zoological Institute of the Russian Academy of Sciences (St. Petersburg, Russia);

cAM - collection of Alexandr Miroshnikov (Krasnodar, Russia);

cSM - collection of Sergey Murzin (Moscow, Russia).

Protapatophysis hindukushensis Miroshnikov, sp.n.

Figs 1, 9, 17, 25, 33 .

Protapatophysis sp.: Miroshnikov, 2014: 19 (Pakistan, Hindukush, Chitral Valley).

MATERIAL. Holotype $\sigma^{7}$ (cAM) (Fig. 1), Pakistan, Hindukush, Chitral Valley, Sussoom, 2900-3200 m, 8.VII.2001, leg. V. Tuzov.

COMPARATIVE MATERIAL. Protapatophysis kashmiriana (Semenov, 1901): lectotype O' (ZIN) (Fig. 5), "Sind River Valley (Kashmir), 7100-7600', 9.-10.VI.[18]98, Novitzky" [in Russian], "Apatophys.[is] kashmiriana m. O" Typ. II.[19]01. A. Semenow det.", golden circle, "Zoological Institute RAN, St.Petersburg", "Lectotypus Apatophysis kashmiriana Semenov, 1901, M. Danilevsky des., 2010".

Protapatophysis montana (Gahan, 1906): holotype $\mathrm{O}^{7}(\mathrm{BMNH})$ (Fig. 8), "Between Gilgit \& Nagy. 93-13.", "Apatophysis montana, Gahan Type", "Type", "Holotypus Apatophysis montana Gahan, 1906" [label by Danilevsky], "Protapatophysis montana (Gahan, 1906), M. Danilevsky det. 2010".

How to cite this article: Miroshnikov A.I. 2020. A new species of the genus Protapatophysis Semenov-TianShanskij et Stshegoleva-Barovskaja, 1936 (Coleoptera: Cerambycidae) from Pakistan // Russian Entomol. J. Vol.29. No.2. P.178-183. doi: 10.15298/rusentj.29.2.09 


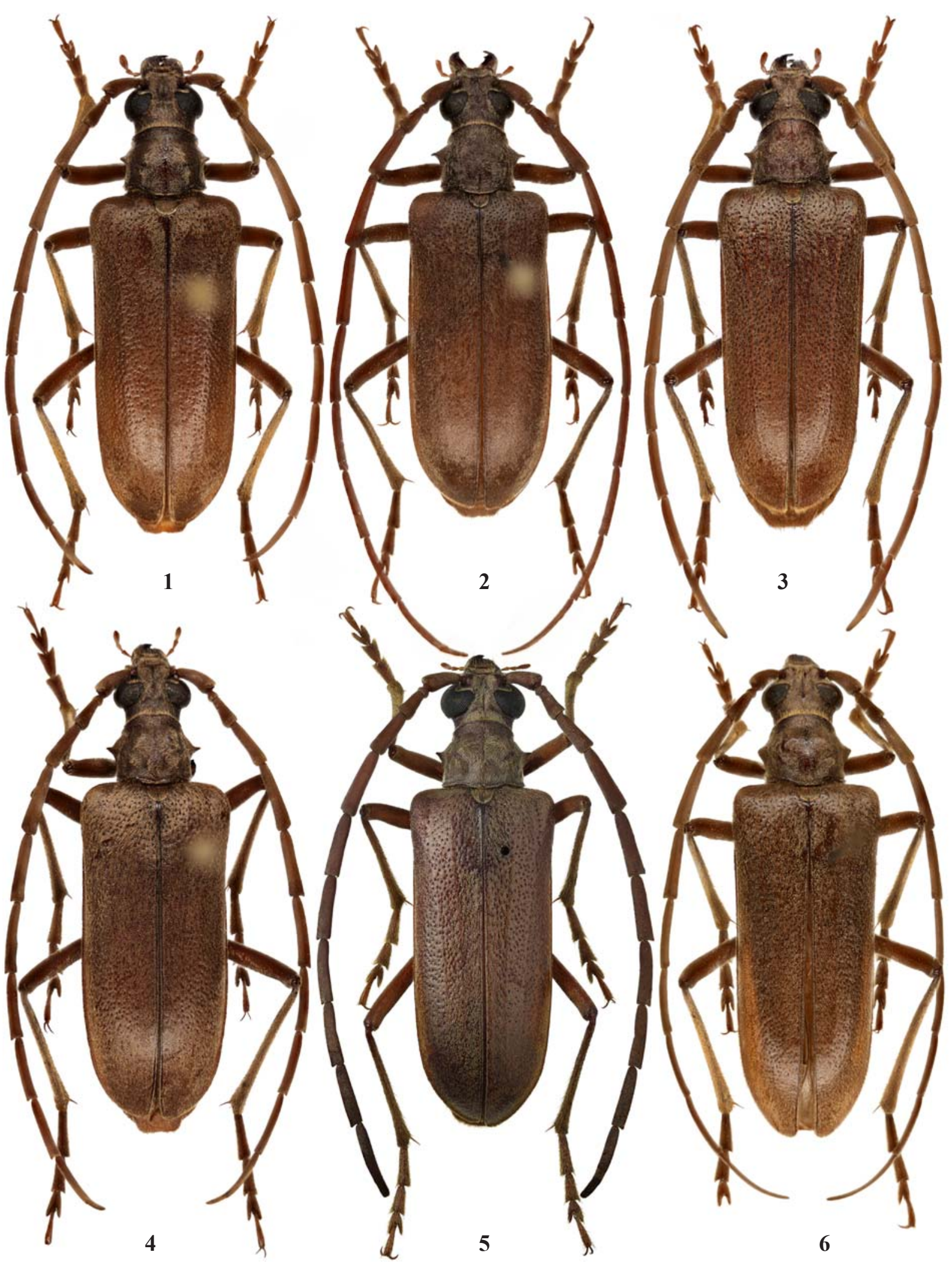

Figs 1-6. Protapatophysis spp., males, habitus, dorsal view: $1-P$. hindukushensis sp.n., holotype; $2-4-P$. vartianae; $5-$ P. kashmiriana, lectotype; $6-P$. kabakovi.

Рис. 1-6. Protapatophysis spp., самцы, общий вид, сверху: 1 - P. hindukushensis sp.n., голотип; $2-4-P$. vartianae; 5 P. kashmiriana, лектотип; 6 - P. kabakovi. 


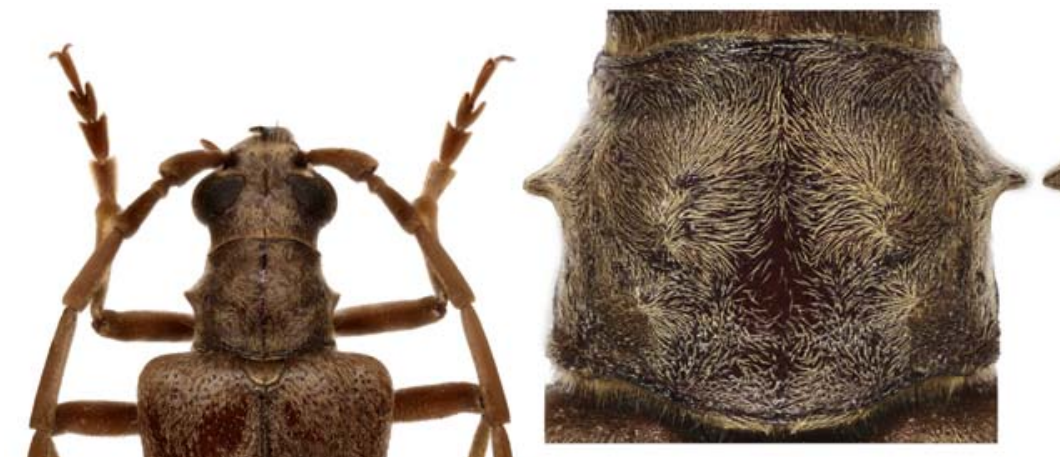

9
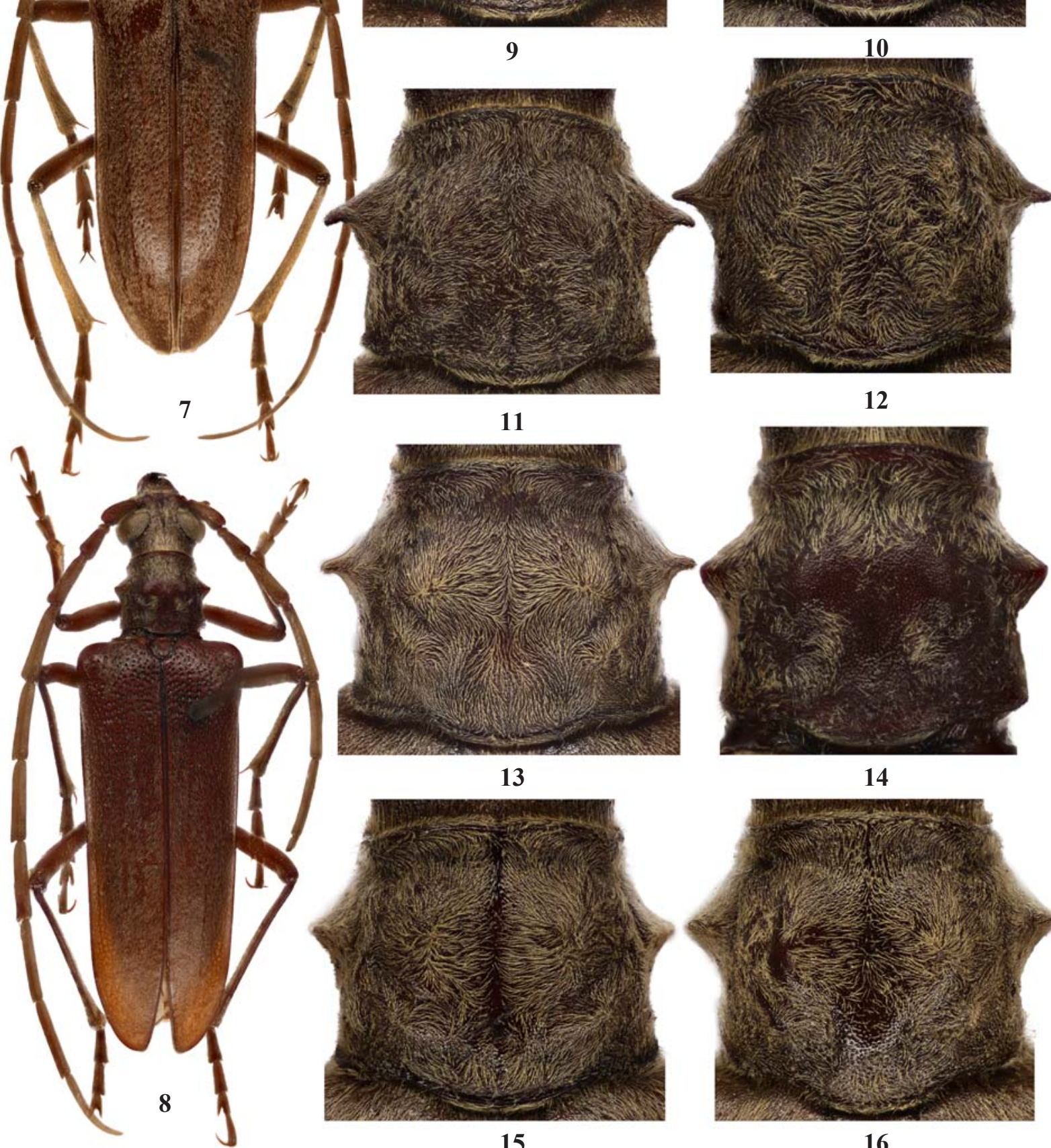

13

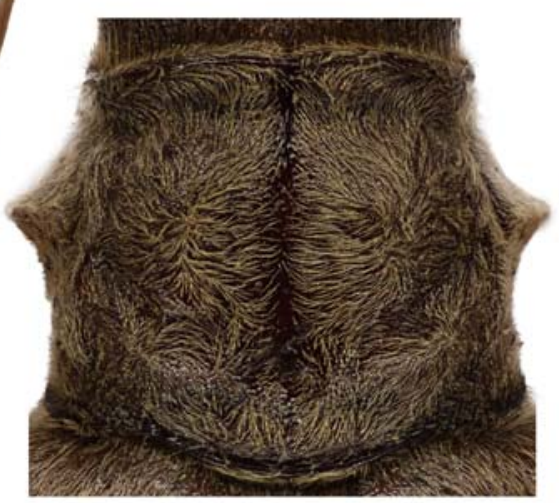

15

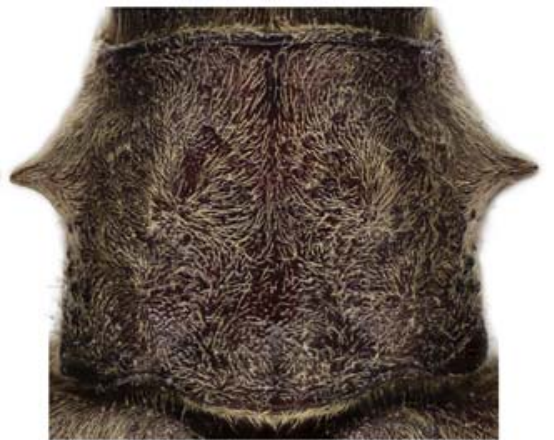

10

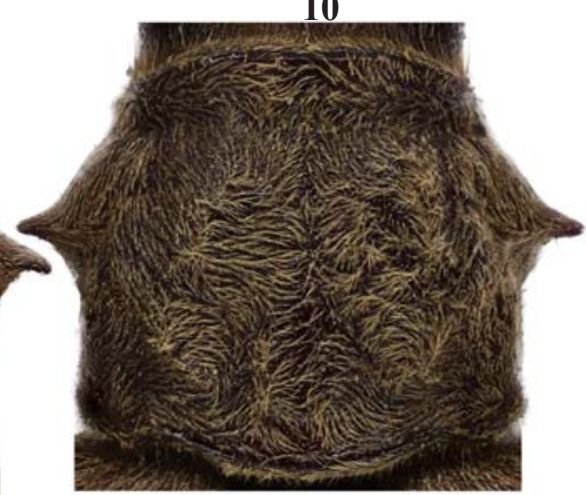

12

14

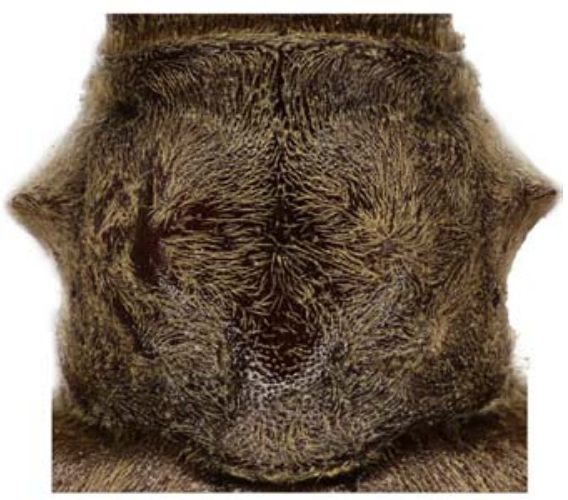

16

Figs 7-16. Protapatophysis spp., males: 7, 15-16-P. kabakovi; 8, $14-$ P. montana; $9-$ P. hindukushensis sp.n.; 10-12 - P. vartianae; 13 - P. kashmiriana, lectotype; 7-8 - habitus, dorsal view; 9-16 - pronotum; 7-9, 14-15 - holotypes.

Рис. 7-16. Protapatophysis spp., самцы: 7, 15-16-P. kabakovi; 8, $14-$ P. montana; $9-$ P. hindukushensis sp.n.; 10-12 - P. vartianae; 13 - P. kashmiriana, лектотип; 7-8 - общий вид, сверху; 9-16 — переднеспинка; 7-9, 14-15 - голотипы. 


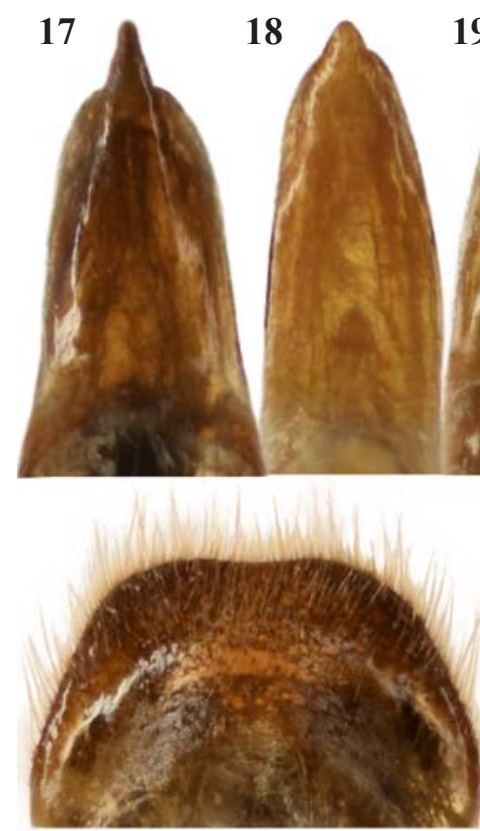

25

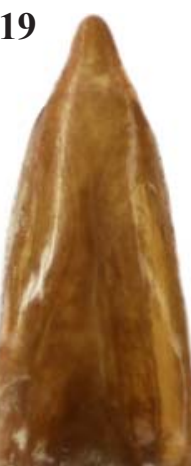

20
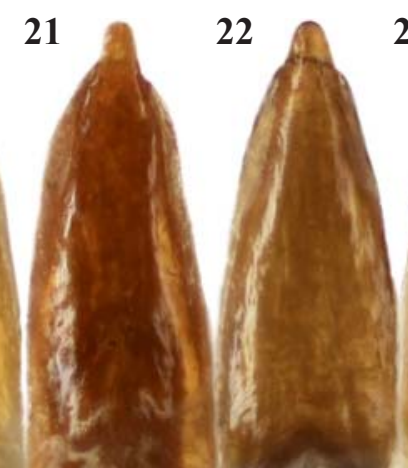

23

24

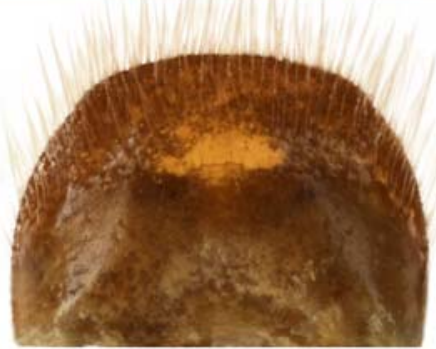

26

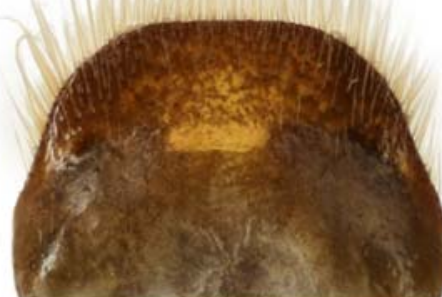

27

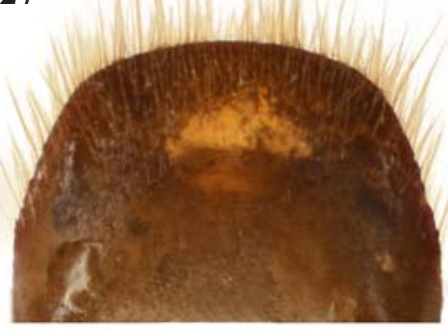

29

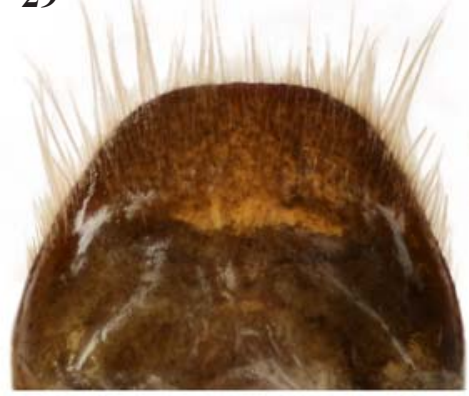

31

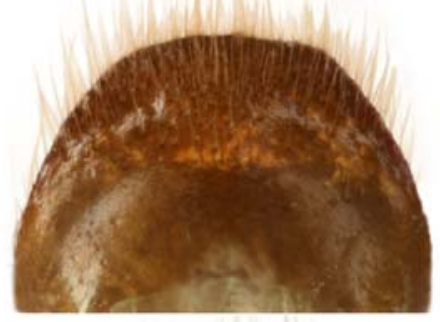

28

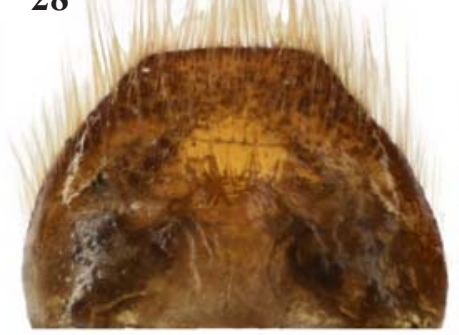

30

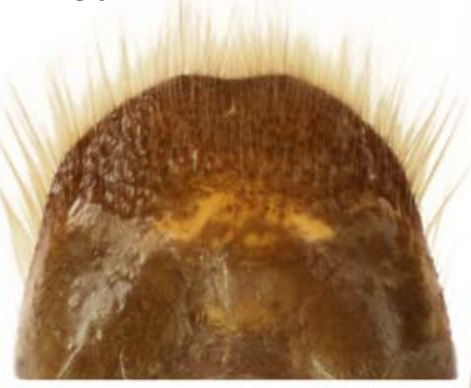

32
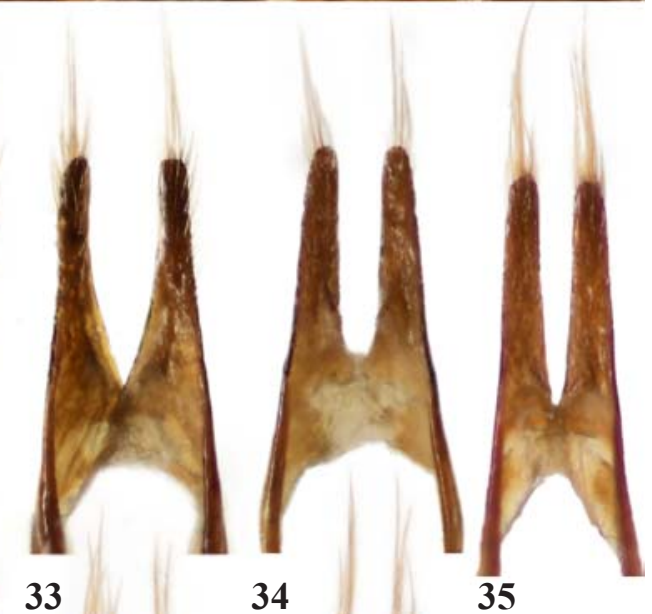

33

34

35

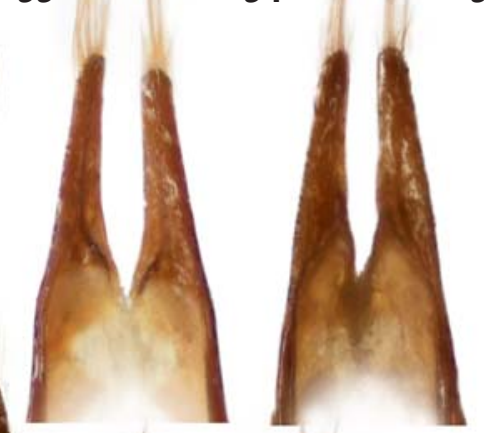

37

36
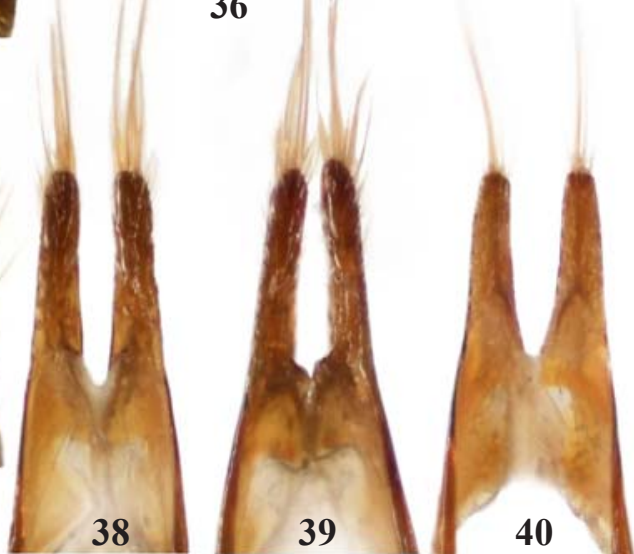

Figs 17-40. Protapatophysis spp., male genitalia: 17, 25, 33 - P. hindukushensis sp.n.; 18-20, 26-28, 34-36-P. vartianae; 21, 29, 37 - P. kashmiriana, lectotype; 22-23, 30-31, 38-39 - P. kabakovi; 24, 32, 40 - P. montana; 17, 22, 24-25, 30, 32, 38, 40 - holotypes; 17-24 - apical part of penis, ventral view; 25-32 - tergite 8, dorsal view; 33-40 - apical part of tegmen, ventral view.

Pис. 17-40. Protapatophysis spp., гениталии самца: 17, 25, 33 - P. hindukushensis sp.n.; 18-20, 26-28, 34-36 - P. vartianae; 21, 29, 37 - P. kashmiriana, лектотип; 22-23, 30-31, 38-39 - P. kabakovi; 24, 32, 40 - P. montana; 17, 22, 24-25, 30, 32, 38, 40 голотипы; 17-24 - вершинная часть пениса, снизу; 25-32 - 8-й тергит, сверху; 33-40 - вершинная часть тегмена, снизу. 
Protapatophysis vartianae (Heyrovský, 1971): 10' (ZIN) (Fig. 2), "Muzaffarabad on Jhelum [River], 17.V.[19]12, Avinov's expedition" [in Russian], "Zoological Institute RAN, St.Petersburg", "Protapatophysis vartianae (Heyrovsky, 1971), M. Danilevsky det. 2010"; $10^{7}$ (cSM) (Fig. 4), "Pakistan, N.W.F. Prov., Mansehra [Distr.], Kaghan Valley, Shogran, 2400 m, 19.VI.2001, leg. K. Stavin", "Apatophysis modica Gahan, 1906, S. Murzin det. 2001", "Protapatophysis vartianae (Heyrovsky, 1971), M. Danilevsky det. 2010"; $10^{7}$ (Fig. 3) (Danilevsky's collection; but this specimen is kept temporarily in ZIN), "Pakistan, Kohistan, Swat prov., Miandam, $1800 \mathrm{~m}, 35^{\circ} 10^{\prime} \mathrm{N}, 72^{\circ} 32^{\prime} \mathrm{E}$, 25.June - 5.July 1992, lgt. Z. Weidenhoffer", "Protapatophysis vartianae (Heyrovsky, 1971), M. Danilevsky det. 2010".

Protapatophysis kabakovi Danilevsky, 2011: holotype o' (ZIN) (Fig. 7), "Afghanistan, Nurestan, Awragal, SW Peè-Dara, $2000 \mathrm{~m}$, [at light, in Russian], 18.06.1971 [O. Kabakov, in Russian]", $A p$ atophysis ?kashmiriana Sem., det. S. Murzin - 1978" [handwritten by Andrey L. Lobanov], "Holotypus Protapatophysis kabakovi sp.n., M. Danilevsky det. 2010"; paratype, $\sigma^{\top}$ (cSM), same locality as holotype, but taken on 20.06.1971, $1400 \mathrm{~m}$, leg. O. Kabakov, "Paratytpus Protapatophysis kabakovi sp.n., M. Danilevsky det. 2010"; $10^{7}$ (ZIN) (Fig. 6), same locality, but taken on 15.06.1971, leg. O. Kabakov, "Apatophysis kashmiriana Sem." [handwritten by Oleg N. Kabakov], "Protapatophysis kabakovi Danilevsky, 2011 O" det. A. Miroshnikov 2019"; $3 \mathrm{O}^{7}$ (cAM), same locality, but taken on $10.06 .1971,17.06 .1971$ and $20.06 .1971,2000$ or $2200 \mathrm{~m}$, leg. O. Kabakov, "Protapatophysis kabakovi Danilevsky, 2011 o" det. A. Miroshnikov 2012".

DIAGNOSIS. Based on male characters, this new species differs from all congeners by the somewhat peculiar shape of the lateral tubercles of the pronotum, as in Fig. 9 (cf. Figs 10 16), the structure of the genitalia, as in Figs 17, 25, 33 (cf. Figs $18-24,26-32,34-40$ ), as well as by the poorly developed discal tubercles of the pronotum and the shorter antennae, especially in comparison with $P$. kashmiriana, $P$. vartianae and $P$. kabakovi (in the latter species, the antennae are sometimes about the same length as in the new species). In addition, $P$. hindukushensis sp.n. is distinguished from $P$. montana by the shape of the elytra (in the latter species, the elytra being more strongly elongated and distinctly narrowed towards the apex), while from P. kashmiriana and $P$. vartianae by the somewhat less strongly developed eyes.

DESCRIPTION. Male. Body length $22.1 \mathrm{~mm}$, humeral width $6.9 \mathrm{~mm}$. Coloration of integument mainly combines reddish brown and brown tones; eyes and partly mandibles black.

Head at eye level distinctly narrower than pronotum at level of lateral tubercles; antennal tubercles very well-developed; median longitudinal groove between eyes clearly visible; with a small dense puncturation dorsally and partly laterally; eyes relatively strongly convex, shallowly emarginate; genae moderately long; submentum with a shallow rugose and scabrous sculpture; gula with gentle transverse wrinkles, on either side of it with irregular puncturation and wrinkles; antennae extending beyond apex of elytra by penultimate antennomere; length ratio of antennomeres 1-11, 39: 7: $28: 46: 61: 58: 59: 57: 57: 58: 76$; antennomere 2 distinctly transverse.

Pronotum very clearly transverse, broadest at level of lateral tubercles where it is 1.3 times as wide as long, base 1.25 times as wide as apex; discal tubercles weakly convex, thereby median tubercle near base not expressed at all; lateral tubercles moderately long, attenuated and sharpened, as in Fig. 9 (in $P$. vartianae and P. kashmiriana, lateral tubercles also attenuated and sharpened, but longer, especially so in the former species, as in Figs 10-13, while P. montana and $P$. kabakovi with subrectangularly protruded lateral tubercles, as in Figs 14-16); on disc with a small, partly heterogeneous, dense puncturation, being sparser at midline in basal part, thereby in this place forming a very well-expressed shiny area with separate setae, as in Fig. 9.

Scutellum widely rounded apically, with very small dense punctures.

Elytra barely narrowed towards apex, look nearly parallel-sided, 2.16 times as long as humeral width; with a rough, relatively regular, moderately dense puncturation being weakened near apex; rounded apically.

Pro- and mesosterna with a clear, transverse, rugose sculpture; metasternum and visible sternites with a small, dense puncturation; metasternum with a sharp median suture; last (visible) sternite very widely, shallowly emarginate apically; last (visible) tergite subtruncate, with a distinct, but not too deep, narrow emargination at apex.

Legs long; femora and tibiae of normal structure; metatarsomere 1 clearly shorter than next two metatarsomeres combined.

Recumbent setation mainly grayish, partly yellowish, being most dense on head dorsally, pronotum, scutellum and tibiae, on elytra poorly hiding their puncturation; erect and suberect, numerous, long setae focused mainly on femora, tibiae, abdominal apex, partly on head.

Genitalia (Figs 17, 25, 33). Apical part of penis as in Fig. 17; dorsal lobe relatively broadly rounded apically, very distinctly wider than ventral lobe near apex (while in other congeners, dorsal lobe narrower rounded apically, as in Figs 18-24, more or less evidently (but not so clearly) wider than ventral lobe near apex); in addition, ventral lobe

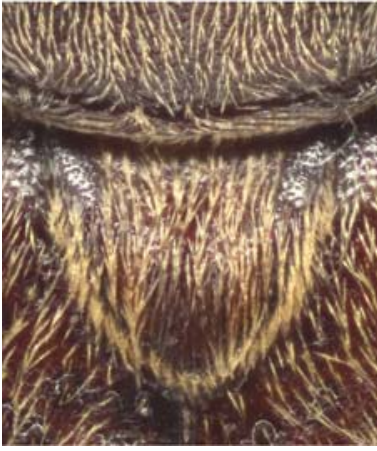

41

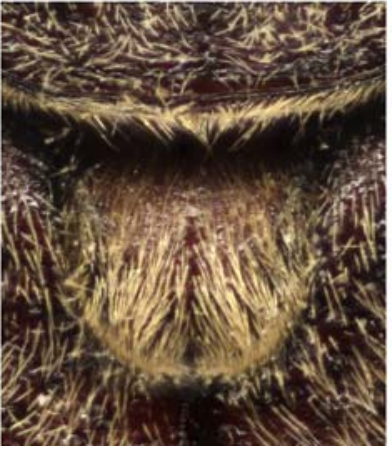

42

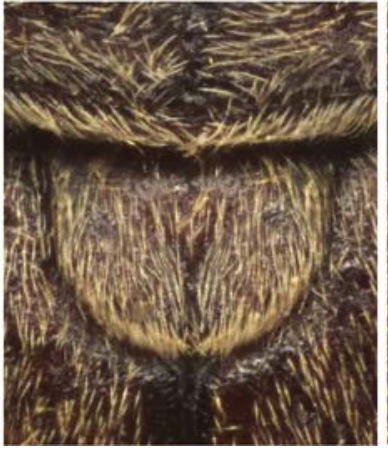

43

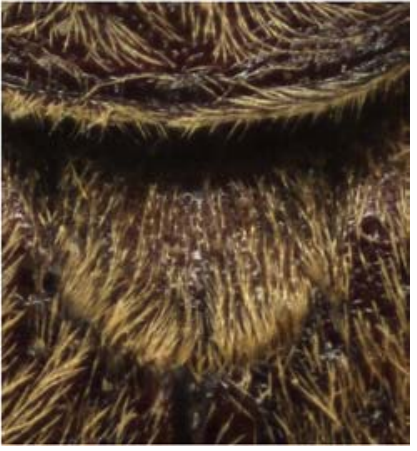

44

Figs 41-44. Protapatophysis spp., males, scutellum: $41-$ P. kashmiriana, lectotype; 42-44 - P. vartianae.

Рис. 41-44. Protapatophysis spp., самцы, щиток: 41 - P. kashmiriana, лектотип; 42-44 - P. vartianae. 
very noticeably extending beyond apex of dorsal lobe, as in Fig. 17 (while in other congeners, ventral lobe somewhat less clearly extending beyond apex of dorsal lobe, as in Figs 18-24). Tergite 8 distinctly broadly emarginate apically, as in Fig. 25 (while in P. kashmiriana, $P$. vartianae and $P$. kabakovi, tergite 8 widely rounded or subtruncate at apex, as in Figs 26-31; only in P. montana, tergite 8 emarginate apically, but not so widely, as in Fig. 32). Apical part of tegmen as in Fig. 33 (in other congeners, apical part of tegmen as in Figs 34-40).

ETYMOLOGY. The epithet of this new species is formed on the basis of the name of the locality it supports.

DISTRIBUTION. Northern Pakistan: Hindukush Mountain Range.

BIONOMICS. The holotype was collected at about 3000 $\mathrm{m}$ elevations. This is the highest locality amongst all members of the genus.

Key to SPECIES OF PROTAPATOPHYSIS, BASED ON O CHARACTERS

1. Lateral tubercles of pronotum attenuated and sharpened, as in Figs 9-13

.. 2

- Lateral tubercles of pronotum subrectangularly protruded, as in Figs 14-16

.. 4

2. Lateral tubercles of pronotum longer, as in Figs 10-13; pronotal disc with or without poorly expressed shiny area in basal part at midline, as in Figs 10-13; antennae longer, as in Figs 2-5; apical part of both penis and tergite 8 as in Figs 18-21, 26-29.

- Lateral tubercles of pronotum shorter, as in Fig. 9; pronotal disc with a very well-expressed shiny area in basal part at midline, as in Fig. 9; antennae shorter, as in Fig. 1; apical part of both penis and tergite 8 as in Figs 17, 25

P. hindukushensis sp.n.

3. Median longitudinal groove between upper lobes of eyes noticeably extends beyond the line connecting their lower margins; scutellum distinctly triangular, narrowly rounded at apex, as in Fig. 41; pronotal disc with a less sharply expressed puncturation

P. kashmiriana (Semenov)

- Median longitudinal groove between upper lobes of eyes distinctly does not reach the line connecting their lower margins; scutellum widely rounded at apex, as in Figs 4244; pronotal disc with a more sharply expressed puncturation ................................... P. vartianae (Heyrovský)

4. Elytra more strongly elongated, distinctly narrowed towards apex, as in Fig. 8; tergite 8 emarginate apically, as in Fig. 32 P. montana (Gahan)

- Elytra less strongly elongated, barely narrowed towards apex, as in Figs 6-7; tergite 8 widely rounded or subtruncate apically, as in Figs 30-31

P. kabakovi Danilevsky

Acknowledgements. I am very grateful to Svetlana V. Andreeva (ZIN), Maxwell V.L. Barclay and Michael F. Geiser (BMNH) for the opportunity to study the museum material, to Sergey V. Murzin (Moscow, Russia) who has provided some specimens from his private collection. I would like to express my sincere thanks to my wife Tatiana P. Miroshnikova (Krasnodar, Russia) for having rendered great help in the preparation of pictures.

\section{References}

Danilevsky M.L. 2011. A review of genus Protapatophysis Semenov-Tian-Shanskij et Stschegoleva-Barovskaia, 1936 stat. nov. (Coleoptera: Cerambycidae: Apatophyseinae) // Studies and Reports. Taxonomical Series. Vol.7. Nos 1-2. P.93-104.

Miroshnikov A.I. 2014. New genera and species of the tribe Apatophyseini Lacordaire, 1869 from continental Asia, with notes on some little-known taxa (Coleoptera: Cerambycidae) // A.S. Konstantinov, S.A. Ślipiński, A.Yu. Solodovnikov (eds.). Advances in studies on Asian cerambycids (Coleoptera: Cerambycidae). Papers by Alexandr I. Miroshnikov, dedicated to the memory of Dr. Judson Linsley Gressitt. KMK Scientific Press Ltd. Krasnodar-Moscow. P.11-50. 